\title{
Surgery, limos and shine keep things going
}

\author{
F.M. Riegler
}

Published online: 5 October 2015

(C) Springer-Verlag Wien 2015

\section{Dear reader,}

Well come to this issue of European Surgery offering you an interesting possibility. Due to a very mute change and a remote chance you find time and space to go through those individual lines. And as you do so you may imagine a basic spectrum of so called matter of facts: a surgeon sees a patient and is, a surgeon communicates with the nursing and technical personal and is, a surgeon gives a talk and is, a surgeon raises his head smiles to the sun and is, a surgeon defines a diagnosis and therapy and is, a surgeon manages an acute abdomen and is, a surgeon plans a surgery and is, a surgeon talks about work-life balance and is, a surgeon offers a novel multidisciplinary treatment algorithm of life style-induced benign and malignant disorders and is, a surgeon puts on her new elegant shoes and is, a highly dedicated surgeon oncologist hides behind a mask and is, a surgeon gets tired and is, a surgeon wishes to have a family and is, an academic surgeon wants to be important, publishes and is. Somewhere out there in the theatron of the Medical University Vienna (MUW), a brave surgeon certainly commonly calculates (CCC) a logistic regression model analysis and "is" $(p<0.001)$. At famous Beth Israel Hospital, Harvard Medical School, Boston, another twisted and well-trained high volume surgeon steps out of his desk and shouts into question: "show me your data!", and "is". At the University Clinic of surgery at the Medical University Innsbruck, a surgeon admires her mountain and is. She knows that she will hike up there soon and is. The clock strikes tower to Puntigam, and a surgeon at the Medical University Graz wants more influence and is. She will get her position, will impair burn out without

\section{F.M. Riegler $(\square)$}

Reflux Medical,

Mariannengasse 10/9,

1090 Vienna, Austria

e-mail: martin.riegler@refluxmedical.com burn and is. At Salzburg Private Medical University para excelcis a surgeon offers Mozart piano lessons and is. This aims to increase her income and is.

You are and understand the common trunk education of the aforementioned suggestions: your perception assesses action, which can be translated into measurable and comparable calculations (excel in excelsis day oh!), but what about the "is"? What compares to "is"? What defines "is"? How can we measure "is"? How can we assess "is"? Or may it be that "is" measures, calculates, dominates, origins, allows us? What swings, sings, grooves, tunes behind the superficial material outbreaks of our perceptions? May it be the "is"? May it be that by asking these very silly questions we reach a fundamental dimension of our reasoning? May it be that this conduct of reasoning offers the breakthrough to the major essence, the essential of our existence: to the being? Science repeats experiments to avoid false data. May it be that "is" does not fit within the scheme of start, end, live, die, false, wrong, good, bad, time, space, greed, envy, power and hate? Who reads these lines "is". As a matter of fact, the universe and stupidity continue to grow and expand. Due to your skills, routine and expertise your patient survives your treatment and is, continues to be. Is that true? Can there be truth without the "is"? Can there be you without the "is"? Can there be questions and answers without the "is"? Throw away your sounds and ask yourself: can there be silence without the "is"? What is the state of mood, where we listen and put attention to the "is"? May it be the state of humility? At this moment, you receive a breaking news facebook message: following emotional tsunamis shaking his worlds up, down, over, through and back again, your older colleague came to death, died and is.

Once upon a space for time makes you to come to an immediate stop of walk during your move from the house to the car in the early morning hour of the day, of your day; watch out it says, cell phone calendar strikes 6:30 a.m. 
(=ante meal, ante moon, ante meeting, ante magic, ante morning, ante mood, ante mirror, ante metastasis, ante myeloma, ante mixture, ante mortem, ante music etc.). Bending back the neck allows your nose, face, hairs and eyes to feel, expose, taste, smell and vision the beautiful breeze of dawn (Fig. 1). The western half of the sky still buries the belt stars of the orion and you remember: the position of those three stars has been modeled and translated into architecture by the architects of the three great pyramids of Gizeh, with the lion sphinx mingling to the rise of the sun within the house of leo, in the east, more than 10,000 years ago [1]. A very ancient legacy arises within the belt of your brain. The other half of the sky offers the multi-layered blue-yellow-red coloured spectrum of the rising shine. And thus, it has been put into song in the golden ages many thousand years ago: God Osiris (= orion) runs towards the assembly of the gods (= dark half of the sky) to inform them about the arrival of god Aton (=the sun). Thus, knowledge of astronomy has been put into myths many thousand years ago. And here you sense that you might have lost much of these feelings for myths and their basic meanings. Perception goes on as you listen to the birds, dogs, cats, who welcome the sunrise of the day. And at this moment, there raises the idea: such beautiful presentation of nature orchestrated by the magic interplay between sun, stars, air, clouds, trees, woods, shadows, light, colours, sounds, smell and vibrations is the perception to the basic questions: why is that? how is that? what does it mean? whom did it pleasure before man, before I have been on the planet? What is the real meaning of this message? May it be that this message teaches us: men and women perceive this mes-

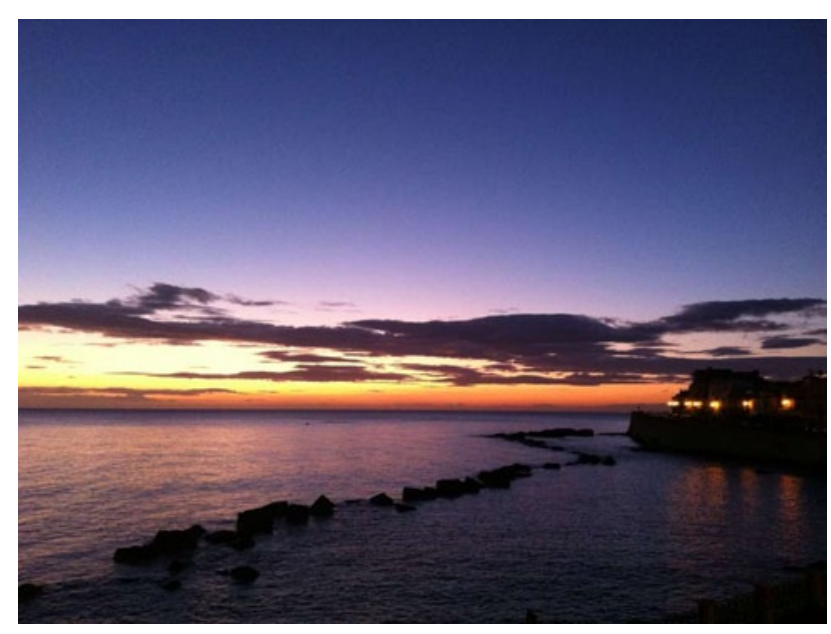

Fig. 1 East: Dawn during sun rise allowing the perception of a particular multi-layered spectrum of colours eliciting a remembrance, which connects us to the very essence of nature, as outlined in the text. Such colourful moods of tune may also have stimulated the ancient Greeks to manifest universe and all their perceptions in the form of temples, theaters, statues, drama and philosophy. Image obtained during early morning dawn, 25.12.2011 Syracuse, Sicily, Italy, EU, using iPhone technology sage and are. May it be, that we should allow ourselves more acute and short moments of: humility, passion, love and gratitude? May it be, that there is a reason why nature sends us these perceptions in order to elicit a particular tune of mood? May it be that this tune of mood should help us to keep off greed, envy, hate and power game for some short moments of the day? May it be that such moments of silence aim to connect us to the stars, moon, sun, winds, plants, animals, universe and thus mirror a special multi spectral time-space, where "being" speaks to us in the form of the LIMOS? (greek: absence of any presence) [2]. May that swing help us to better overcome the circumstances around the job at the hospital, the hostilities with colleagues, the stress and pressure from all sides of the archetype hierarchy pyramid of the modern struggling health system? May this early morning perception help you to be better at playing the mask for you, hide against others and play for yourself, only? Or may that sign motivate you to allow to consider a transient or permanent step out of this well-calculated system? May it be that you may have some power and segment of life where you are allowed to decide? It seems the legacy teaches: be you and withstand the despotic power games as much as you can. In case you harbour the personality for a leader in the power game: enjoy the position, but do not forget, you are a day, and every day includes a twilight (Fig. 2), and your twilight is going to come, too, for sure. Maybe you wish to have a soft twilight without pain, suffer and cry? Thus, take the message of the dawn: think pure and essential. Now you may step into your car, start the engine and drive it to the hospital. Here you envision the representation of the driving force

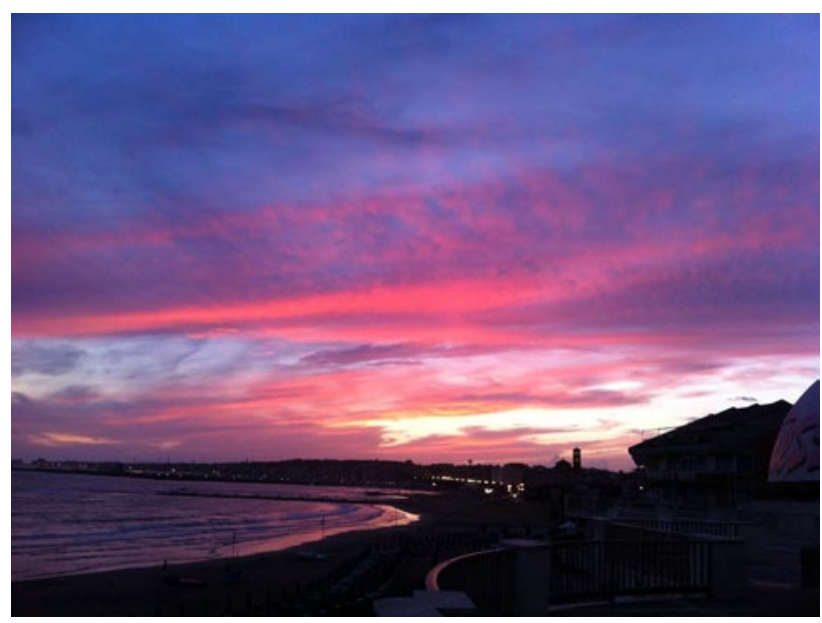

Fig. 2 WEST: Twilight after sunset allowing the perception of a very specific multi-colour tune of mood image, which mirrors the idea of the author, that every rise harbours a set and every set harbours a rise. This circuits of tunes of mood orchestrate the perception within the process of being (=man watches and is), as outlined in the text. Image includes the beach where the author Robert Musil sets and locates the incest between Ulrich (Osiris) and Agathe (Isis) in his novel entitled: The man without qualities. Image obtained on 04.09.2015, Nettuno, Italy, EU 
of all perceptions: the "must shine"! The must to come into the front of perception against any background! The desire to come into the attention of others! The wish to remove others from being perceived! To over-shine! The continuous process of a must to be important and powerful! You may call it power, gravity, will, being, matter of facts etc., it is the driving force of change. The world is thought as it is, and it is the continuous competitive "must shine" against, beyond and out of the limos and against all other possible perceptions, and nothing else, at all [2]. In other words, our reasoning models the world in the following way: all wants to shine and be in front and be important and famous versus its background and all other perceivable possibilities. Therefore, this "must shine" drives the world as we perceive it and keeps it in motion and going. As a consequence, the "must shine" seems to stand behind all perceptions, all perceptions seem to be the manifestations of the continuous and permanent "must shine". Taken together, the "must shine" seems to evolve out of the limos and seems to accurately model the essence itself: being.

And as you find yourself within the morning conference (7:30-8:00 a.m., or 8:00-8:30 a.m.), you may see that everyone WANTS to shine, but only FEW are allowed to shine. The boss (sun or moon?) allows light and shine! And here starts the problem. Remains to be questioned the present ongoing "new" representation of the "must shine" before the background of others who wish to come into shine?

Going in line with our recent cautious estimations [3], the major and profound geo-sociopolitical changes around the "mare nostrum" continue to follow the anticlock direction and definitely reach the west Asian part of the large continent. How did it evolve to be named Europe? We are all aware about a god-bull, not red, a young girl. And the girl has been taken by the bull to the island. From there the culture did continue to spread all over the "mare nostrum". Irrespective of the time (past, present, future), we are all coming from Africa (Lucy Leakey weekly weak in the sky with diamonds). Thus, it can be concluded: we are all Africans! Thus, we are to be congratulated for the notion: welcome brothers and sisters, victims of those, who failed, victims of those, who have a well-paid job (ca. 20,000-30,000 € per month), that requires nothing more than having no senses of any responsibility, except to save his or her own belongings within the pulsatile profit bearing shark rattled liver snake pool. This is the true revelation of socialism (Greek: sozein = save): politics seem to be the devil presentation of the world soul and shake the planet. In addition, the multi-spider power network of industries (weapon, nutrition, pharmaceutical, medical, communication, mobility, clothing, wellness etc.) and the ocean wall tide adjuvant bank system definitely strike out to orchestrate the upcoming cataclysm of the Western civilization. Did those within the present wave of migration come to take over? Remains to conduct the exodus to survival: author- ity of knowledge, open mind set and discipline, in order to strengthen the organism, preserve health and power to withstand what may be going to come. Taken together, we are all one union and highly vulnerable. According to the state of science: there is no other planet where man finds the prerequisites to live, except ours. Unfortunately, this is not adequately perceived by the majority of human beings. Therefore happens exodus, floods, diseases and surgeries.

The alphabet: a beautiful crystal diamond evening figures great hidden instinct jealousy, kings let mighty network organisation players question rude system tunings, uttermost victory waves xyphoid yield zodiacs. Manus Caesaris ad regionem eigastrica demonstrat et indicat possibilitatem tumoris gasteris. Problema pro Caesarem erat: Napoleonus non habebat aram pacis (sive Augustus in Roma antiqua). Si polarisatio sub sole non existat, quid necesse est pro vitae ordo, subjectum in objecto incidiendum est. Consequentia appelatur: Waterloo individualis sub specie aeternitatis.

The present issue of European surgery offers the work of open-minded, highly motivated academic surgeons and summarises some aspects of the fascinating spectrum of modern medicine and brain work. We have outstanding talents, we have amazing multidisciplinary ideas, so let us continue the legacy of our ancestors: man thinks wise and "is". Surgery cuts, dimensions fuse and process fosters change. We should never stop to reason to ask those very silly questions: What about "is" and chance? Stay tuned, enjoy your day, foster happiness and balance. A star shines within YOU and is.

\section{Martin Riegler}

\section{Acknowledgments}

The author thanks being for revealing short silent moments of intensive perception of the essence. In addition, the author thanks his patients, who enable the repeated understanding of the story process of beingsick. Without the perception that disease means being, the fundamental importance of medicine/surgery is not adequately taken. Finally, the author thanks his family, teachers, mentors, friends, and the blue skies above, which are suggested to hide us, that is the universe.

\section{Conflict of interest}

The author declares that there is no conflict of interest.

\section{References}

1. Hancock G. Magicians of the Gods. London: Coronet, Hodder \& Stoughton Ltd.; 2015. p. 192-198.

2. Riegler FM. Surgery today: smile clears the tide. Euro Surg. 2014;46(6):227-30.

3. Riegler FM. Essence-based surgery: a taste for fruitful reasoning. Euro Surg. 2014;46:49-51. 